\title{
Exotic Insects in Italy: An Overview on Their Environmental Impact
}

\author{
Costanza Jucker and Daniela Lupi \\ University of Milan/DiPSA \\ Italy
}

\section{Introduction}

Hundreds of alien arthropods, native to different continents or introduced from other parts of Europe, have been recorded in Italy in the last few decades (Jucker et al., 2009; Pellizzari \& Dalla Montà, 1997; Pellizzari et al., 2005). Italy is at high risk of introduction of exotic insects, particularly because of the country's climatic conditions, which support many subtropical species, and its position in the middle of the Mediterranean Sea, which makes Italy a commercial and tourist crossroad. Invasion is a normal ecological process, but it can be incentivized by human activities with processes far more rapid than those that occur in purely native systems. Biological invasion by exotic species is considered one of the main threats to the loss of biodiversity; it can cause enormous damage in terms of socio-economic costs, harm human health, and result in ecological losses (Kenis et al., 2009). The rise in economic costs can be attributed to yield losses, in agriculture and horticulture, or to increases in the production costs for pest management. The severe economic impact of these species is evident: the crudest estimate of the total known monetary impact of alien species in Europe is close to 10 billion euros annually (COM, 2008). Moreover, the damage to human health leads to major costs connected to control programs and public health measures. Damage is due to irritation and disease transmission by hematophagous species, or to allergies, and other maladies by other groups of insects.

The introduction of a species affects the ecosystem of the new habitat in different ways: the invasive species can be a herbivore, predator, or parasitoid, and can compete with indigenous species via different interactions (competition, disease transmission, hybridization). The major pathways of arthropod migration are indeed accidental, represented by different means of transports, the trade in ornamental plants and other goods, and tourism; natural climatic events can also be responsible for the movement of arthropods. We likewise have to consider that sometimes the introduction of the invasive species is voluntary, and even if the insect itself is helpful, can become a serious threat to a country's biodiversity. The deliberate introduction into the new environment can be for productive purposes or as a control agent (the classical biological control, based on importation of natural enemies from the country of origin of the exotic pest). Rodolia cardinalis (Mulsant), imported in California in the late 19th century to control cottony cushion scale, has ever since been a textbook example illustrating the accomplishments of biological control. 


\section{Factors influencing alien species establishment and spread}

Only some alien arthropods become significant as an outcome of invasion; whether this happens depends both on the species and on the susceptibility of the invaded ecosystem. Moreover, once the species has settled, damage can be heavy only when the population is sufficiently numerous. Activities such as agriculture, logging, and grazing enhance the establishment of exotics by creating disturbed sites for colonization (Sakai et al., 2001). However, we consider the climate, the hosts, the presence of natural enemies, the reproduction strategies, and habitat fragmentation as the factors that strongly influence the settlement of the alien species in the new environment and make it invasive.

\subsection{Climate}

Among the factors that influence the settlement and the invasiveness of a species, one of the most important is the climate and, consequently, the synchronization of the lifecycle in the new habitat. The climate effect is more evident in arthropods because they are poikilothermic, which means that temperature strongly influences their development.

A species may arrive in a new potential habitat, but the differences between the season and the instar of development of the insect may not allow the species to survive and settle. There have been many interceptions of dangerous pests that would not have even survived in the new habitat. Leucinodes orbonalis Guen. (Lepidoptera, Pyralidae), which was included in the European and Mediterranean Plant Protection Organization (EPPO) Alert List after more than 120 interceptions of infested Solanum fruits imported from Asia and Africa were made by several EPPO member countries (EPPO, 2011), can be reported as an example of this lack of synchronization in Italy. In our country the species was detected as larvae during phytosanitary control on easter eggplant fruits at Milan Airport in winter (Jucker et al., 2007), a period not suitable for insect development. We cannot exclude the possibility, however, that arrival in a more favorable season would allow this species to settle.

Sometimes a species of tropical or sub-tropical origin that cannot survive winter in a temperate climate can overcome this difficulty by entering greenhouses or houses. Trialeurodes vaporariorum (Westwood) (Hemiptera, Aleyrodidae), Leptoglossus occidentalis Heidemann (Hemiptera, Coreidae), and Harmonia axyridis Pallas (Coleoptera, Coccinellidae) are just a few examples of the application of this strategy in Italy. T. vaporariorum, accidentally introduced into Europe and Italy in the middle of the 19th century, is originally a sub-tropical species; although it can withstand slight frost for a short time, it overwinters in glasshouses in areas of colder climate. L. occidentalis, discovered near Vicenza in Northern Italy in autumn 1999 (Tescari, 2001), and H. axyridis, reared and introduced as a biocontrol agent (Pervez \& Omkar, 2006), can survive in unfavorable low temperatures by entering houses at the onset of cold weather in search of a protected site to spend the winter.

Global warming can also influence alien species settlement (Perrings et al., 2010). Climate change, in fact, is expected to alter biodiversity, causing variation in phenology, genetic composition, and species ranges, and affecting species interactions and ecosystem processes both in autochthonous and in exotic species (Sutherst, 2000). Global warming could provide new opportunities for introduction to areas where, until recently, introduced species were not able to survive. The Mediterranean fruit fly Ceratitis capitata Wiedemann (Diptera, Tephritidae), a highly polyphagous quarantine pest that probably originates from subSaharan Africa, has limited its distribution to areas under the $41^{\text {st }}$ parallel. In northern Italy, with its normal climate conditions, the insect is not able to overwinter in the field at 
preimaginal stages, although adults can survive indoors and at temperatures higher than 10$12^{\circ} \mathrm{C}$ for prolonged periods (Rigamonti, 2004). However, global warming may allow stable colonization of C. capitata populations at higher latitudes than at present.

Moreover, a country's climatic situation can be favorable to a major or minor number of generations per year; it can influence the oviposition period, number of eggs, preimaginal development, and adult survival, and it can also make a species more or less aggressive. An example is Lissorhoptrus oryzophilus Kuschel (Coleoptera, Erirhinidae), one of the major insect pests in rice-growing regions of the United States, China, Japan, and Italy. This species is univoltine in many areas, including Italy, but it can be bivoltine or multivoltine in regions where the climate is warmer (Chen et al., 2005; Lupi et al., 2007; Shang et al., 2004).

\subsection{Host}

There are numerous examples of successful adaptation to Italian environments because of the presence of valuable hosts. We have to consider that many invading species are polyphagous, so they have a higher potential of establishment than do monophagous or oligophagous species.

Sometimes in the country of origin the insect coevolves with its host, and the development on other hosts in different countries (either varieties or species) leads to major damage. One of the first invasive agricultural insect pests that hit the Italian economy in the past was the American vine phylloxera, Viteus (=Daktulosphaira) vitifoliae (Fitch) (Hemiptera, Phylloxeridae) (Strapazzon \& Girolami, 1983). Detected in Europe in the late $19^{\text {th }}$ century, it is an example of the complexity of the host-plant relationship. Within the natural range of diffusion of phylloxera and its host, Vitis vinifera plants show very little damage from the aphid (Gullan \& Cranston, 2010). The situation was different upon its arrival in Europe, where plants had no resistance to the aphid: on $V$. vinifera European species, the insect produces nodose and tuberose galls on the subapices of young roots, causing incalculable economic damage and social consequences (Kenis \& Branco, 2010). The problem was largely solved by replanting European cultivars grafted onto resistant American rootstocks. The Asian black hornet Vespa velutina Lepeletier (Hymenoptera, Vespidae) is an example of predator-prey coevolution. This wasp is endemic to southeast Asia, where it is a predator of social wasps and bees, including both the native Apis cerana F. and the introduced Apis mellifera L. (Hymenoptera, Apidae). While A. cerana colonies have evolved defense strategies against $V$. velutina, the European honeybee sustains significantly greater losses (Tan et al., 2010). Even if the insect is not yet arrived in Italy, our country is at high risk of introduction because the insect has already settled in southwestern France (Haxaire, 2006).

Sometimes the species becomes invasive only after a host shift. An example is the rice water weevil L.oryzophilus, which was originally confined to spontaneous gramineous and cyperaceous plants in North America. When rice was introduced in the area where the insect lived, there was a host shift to it and the insect invasion started (Chen et al., 2005; Lupi et al., 2010). However, rice is not enough for insect development as spontaneous plants are still necessary in the spring, when the adults emerge from overwintering sites and rice is not yet emerged (Lupi et al., 2009; Tindall \& Stout, 2003).

\subsection{Natural enemies}

When an exotic pest colonizes a new habitat, the absence of natural control agents can contribute to its settlement and to the consequent damage. Sometimes research in the 
country of origin can be useful in finding natural enemies as an alternative to chemical control. In fact, in many situations biological control could represent a valid and stable help to manage both autochthonous and exotic pests.

Among the recent examples of classical biological methods applied to introduced pests in Italy, we have to mention Neodryinus typhlocybae (Ashmead) (Hymenoptera, Dryinidae) and Torymus sinensis Kamijo (Hymenoptera, Torymidae). In 1987, N. typhlocybae was introduced in Italy into the Veneto region for the biological control of Metcalfa pruinosa (Say) (Hemiptera, Flatidae). First detected in Italy in 1979, this planthopper native of the United States rapidly spread because of its polyphagy and lack of natural enemies (Strauss, 2009; Zangheri \& Donadini, 1980). Among the parasitoids in North America, N. typhlocybae was considered the most promising control agent. For this reason, a biological control project started in Italy at the end of the 1980s to import the parasitoid. Larvae develop as ectoparasitoids of M. pruinosa immatures, and adults also feed on the host, thus augmenting pest mortality. Over the past years, this insect has been successfully released in many urban and agricultural areas of Italy, and this has resulted in its establishment (Alma et al., 2005). The classical biological method based on the use of the parasitoid T. sinensis seems to be the most effective in reducing the populations of Dryocosmus kuriphilus Yasumatsu (Hymenoptera, Cynipidae), a species of Chinese origin that attacks chestnut trees and that invaded Japan, Korea, Nepal, the United States, and Europe (Brussino et al., 2002; Moriya et al., 2003; Quacchia et al., 2009). Removing twigs or protecting them with nets proved to be very labor intensive and produced little results. Chemicals were also inefficient as the immature stages are protected within the gall.

New interactions among recently introduced species and endemic natural enemies are also very important. Again, D. kuriphilus and $H$. axyridis can be used as examples. It has been reported in many countries and apparently in Italy as well that D. kuriphilus, when established, rapidly recruits parasitoids attacking oak gall wasps locally (Aebi et al., 2007) and that $H$. axyridis can be parasitized by Dinocampus coccinellae (Shrank) (Hymenoptera, Braconidae), a general parasitoid of Coccinellidae present in Italy (Dindo et al., 2011). The relationship among alien pests and autochthonous useful species is particularly remarkable when the origin of a species is unknown or few data are available on natural enemies in the native country. We refer to the horse chestnut leaf miner Cameraria ohridella Deschka and Dimic (Lepidoptera, Gracillariidae), described as a new species in Macedonia and whose origin is still under debate (Deschka \& Dimic, 1986; Valade et al., 2009). Detected in Italy in the 1990s, it spread rapidly and caused a great deal of aesthetic damage to the plants it attacked. Studies on this species showed that numerous native parasitoids adapted to C. ohridella with, sometimes, a very high parasitization percentage (Lupi, 2005; Gröbler \& Lewis, 2008; Grabenweger et al., 2009). We also refer to Anoplophora chinensis Forster (Coleoptera, Cerambycidae), the citrus longhorned beetle, for which information on parasitoids in the native country is lacking. Studies carried out in Italy led to the detection of some polyphagous endemic parasitoids and the Asiatic egg parasitoid, Aprostocetus anoplophorae Delvare (Hymenoptera, Eulophidae) , probably introduced with $A$. chinensis and the efficacy of which is still under study (Delvare et al., 2004; Hérard et al., 2004). Studies concerning the presence of natural enemies of Cacyreus marshali Butler (Lepidoptera, Lycaenidae) in Italy gave evidence to the presence of the oophagous Trichogramma evanescens (Westwood) (Hymenoptera, Trichogrammatidae), already detected in other European countries, and of the larval parasitoid Aplomya confinis Fallen (Diptera, Tachinidae) (Vicidomini \& Dindo, 2006). 


\subsection{Reproduction strategies}

Among the traits that promote successful invasion after initial colonization, there is the establishment of a self-sustaining population. Reproduction strategies that feature the ability to reproduce asexually or to shift between $\mathrm{r}$ - and K-selected strategies seem to play a really important role in this process (Sakai et al., 2001). Among insects reproducing sexually at low densities in the founder population, the efficiency in mate finding can influence insect settlement. The ability to reproduce asexually overcomes this difficulty and facilitates the settlement. Because the founding population of an invading species often suffers from a lack of genetic diversity, organisms that reproduce sexually could be more prone to extinction because of inbreeding (Liebhold \& Tobin, 2008). Hoffmann et al. (2011), evaluating two databases from North America and Italy, found that parthenogenetic species cover $45 \%$ (North America) or $48 \%$ (Italy) of pest species derived from genera where parthenogenesis occurred. They concluded that several factors may contribute to the high incidence of parthenogenesis among pests. The most likely factor is a stable and uniform agricultural environment with an abundance of resources. In such a habitat, the same genotype may be continuously favored by selection, leading to a selective advantage of some parthenogenetic lineages over a sexual population. Among the successful parthenogenetic species in Italy we have to mention many Hemiptera. Moreover, Lissorhoptrus oryzophilus is a parthenogenetic species in nearly all colonized areas and in Italy (Lupi et al., 2007).

The lack of genetic diversity has a notable exception in the Argentine ant Linepithema humile (Mayr) (Hymenoptera, Formicidae), for which reduced genetic variability likely enhanced the invasion success (Suarez et al., 2008). Native to South America, it is now a cosmopolitan pest. In its area of origin the species has a social system with multicoloniality and systematic aggression between workers from different nests, while in invaded countries, it exhibits an extraordinary social organization, called unicoloniality, in which individuals mix freely among physically separated nests because of a loss of aggression between colonies having the same recognition alleles. From 33 Argentine ant populations collected along the Mediterranean and Atlantic coasts from Portugal to Italy, it was established that in this area there are only two supercolonies and that aggression never occurred between individuals from the same supercolony, even when taken from very distant nests (Giraud et al., 2002).

\subsection{Habitat fragmentation}

Both long-distance dispersal and stratified diffusion can greatly increase invasion rates: short-range expansion is mainly due to insect adult active dispersal flying, crawling, and swimming, whereas long-range expansion is due to accidental movements caused by human transportation. The alteration of land-use patterns has resulted in the fragmentation of habitats, ecosystems, and landscapes in most parts of the world, and several theoretical explorations indicate that spread rates are affected by habitat fragmentation (Hoffmeister et al., 2005; Perrings et al., 2010). In fragmented habitats very specialized species or those species with poor dispersal ability may suffer more than generalistic and invasive species. The Italian outbreaks of Cameraria ohridella, Diabrotica virgifera virgifera, and Lissorhoptrus oryzophilus have expanded by stratified dispersal, involving both continuous diffusion and discontinuous long-distance dispersal (Ciosi et al., 2011; Gilbert et al., 2004; Lupi et al., 2010).

\section{Secondary effects of alien species introduction}

Many alien species are dangerous not only for the direct damage they can cause, but also for their secondary effects. Invasive species can act as vectors for pathogens both to plants and 
to humans. The impact of invasives on native species, communities, and ecosystems has been widely recognized for decades. Ecological interactions between native and invasive species may be direct (predation, herbivory, parasitism, competition, mutualism) or indirect (habitat alteration, apparent predation, cascading trophic interactions) and result in changes in the population biology of the native species.

\subsection{Pathogen transmission}

Alien species can behave as vectors of pathogens (e.g., nematodes, fungi, viruses, bacteria) to both plants and animals.

Hemiptera are known for their aptitude to transmit pathogens. Among them we have whiteflies, aphids, psyllid, and leafhoppers. Scaphoideus titanus Ball (Hemiptera, Cicadellidae), a leafhopper introduced in Europe from North America and currently spread in vineyards, is the vector of Flavescence Dorée, a quarantine grapevine disease caused by the bacterium 'Candidatus Phytoplasma vitis' (Angelini et al., 2001).

Among thrips, Frankliniella occidentalis (Pergande) (Thysanoptera, Thripidae), a North American invasive species introduced in Europe in 1983 and currently widespread, is the main vector of the tomato spotted wilt virus, a serious disease in several economically important crops worldwide and in many wild plants that can behave as reservoirs for the virus in the environment. This disease was first described in Australia in 1915 (Brittlebank, 1919). In Europe the virus was present before the Second World War, but the malady was noticeable only when F. occidentalis arrived as the preexisting vector, Thrips tabaci (Thysanoptera, Thripidae), has a low transmission rate (Inoue \& Sakurai, 2006).

Coleoptera are important as they can be vectors of wood nematodes. The presence of the pinewood nematode Bursaphelenchus xylophilus Steiner \& Buhrer, a major threat to pine forests in Japan, is remarkable. This quarantine disease, whose vector is the cerambycid Monochamus alternatus (Coleoptera, Cermabycidae) Hope, has been found in Europe, particularly in Portugal (Mota et al., 1999). In Italy neither the insect nor the nematode has been detected so far.

Many insects can bite and transmit disease, at least potentially. An Asian mosquito species, Stegomyia albopicta (Skuse) (sensu Reinert et al., 2004) (Diptera, Culicidae), often referred to as the "tiger mosquito", is the vector of major human diseases such as dengue, yellow fever, the West Nile virus, and chikungunya (Eritja, 2005). This species began to spread worldwide in the 1970s thanks to the marine transport of tires and other goods, leading to colonization of many areas of the world. European concern rose when the species was detected in Italy, first in Genoa and one year later near Padua (Dalla Pozza \& Majori, 1992). Fortunately the species has invaded many countries without carrying human pathogens. However, we cannot ignore the unexpected outbreaks of chikungunya fever in northern Italy (Angelini et al., 2007), the sudden appearance of West Nile virus in North America, and the increasing frequency of Rift Valley fever epidemics in the Arabian Peninsula.

\subsection{Autochthonous species competitiveness}

Many studies have documented invaders that show a superior ability to exploit local resources as compared with native residents (Bazzocchi et al., 2004; Burgio et al., 2008; Holway, 1998) or as compared with non-invading introduced species. The Argentine ant (Linepithema humile) is not only an agricultural and house pest but is also competitively superior to the native ant species in both interference and exploitative competition in the 
riparian woodlands of northern California and in the alteration of plant community structure (Holway, 1998; Suarez et al., 2008).

The intentional introduction of natural enemies for biological control has raised some criticism (Michaud, 2002) on the potentially negative effects induced by exotic species on indigenous natural ones and, in general, on non-target native taxa (Howarth, 1991; Pearson \& Callaway, 2003; Van Lenteren et al., 2003). We must consider that the more a natural control agent is specific, the less negative the impact is on the environment. Predators have a generally wide range of hosts whereas parasitoids are usually more specific and so potentially less invasive. The coccinellid $H$. axyridis, a voracious predator native to southern Siberia, China, Taiwan, Korea, and Japan, is a major example of this impact. This coccinellid has been introduced in North America and Europe to control aphid and scale populations, and has settled (Pervez \& Omkar, 2006). H. axyridis has been used in greenhouses since the 1990s, and its negative impact was already reported in 1995 in America. Nowadays this species is considered the most invasive ladybeetle in the world: it reduces the biodiversity of the new colonized areas, directly affecting useful insects, replacing the native ladybeetles, and altering the ecosystem equilibrium (Alyokhin \& Sewell, 2004).

\subsection{Landscape alteration}

Alien species invasion can contribute to landscape alteration. This effect can be due directly to insect feeding or indirectly to the necessity of altering the environment because of eradication programs. The devastating impact of the introduction of the red palm weevil Rhynchophorus ferrugineus (Olivier) (Coleoptera, Curculionidae) on landscape palms is well known (Jucker et al., 2007; Longo \& Tamburino, 2005; Sacchetti et al., 2005). In many coastal areas in Italy the urban landscape is principally based on palm, and many of such palms represent a patrimony of high value. The settlement of this weevil in our country represents a serious environmental problem liable to have significant repercussions both on the landscape and on tourism. Eradication programs that consist in the removal of trees infested with Anoplophora chinensis, detected in northern Italy (Colombo \& Limonta, 2001a), are altering the landscape of many areas, especially urban and suburban (Maspero et al., 2007).

Another example of habitat alteration is correlated to the voluntary introduction of the Ailanthus silkmoth (Samia cynthia), a saturniid moth, used to produce silk and introduced in Italy at the end of the 19th century as a possible alternative to Bombyx mori. The impact of this insect on biodiversity has been indirect because the insect itself cannot be considered an invasive insect as it does not threaten any other species, nor does it invade the niche of others. Its introduction, however, was associated with that of its preferred host, Ailanthus altissima, a deciduous tree indigenous to China, which is a serious threat to ecosystems in introduced areas, as the plant is very competitive and it contains allelopathic chemicals that may inhibit the growth of surrounding native plants (Heisey, 1990).

\subsection{Human nuisance}

Sometimes the insects do not transmit pathogens but annoy humans and cattle. Examples are Leptoglossus occidentalis and Harmonia axyridis, which do not bite, sting, feed on people and pets, or reproduce inside the house, but disturb because of their large number in houses, buildings, and food industries, and because they can give off a pungent odor when touched. The habit of $H$. axyridis to aggregate on grapes in vineyards before harvest also results in great consequences for the grape industry (Linder et al., 2009). Further cases are reported of $H$. axyridis leading to patient complaints and symptoms of rhinitis, wheezing, and urticaria after exposure to the beetles (Albright et al., 2006; Yarbrough et al., 1999). A 
problem, encountered in crowded parks in cities, is represented by the presence of species of the genus Corythucha (Hemyptera, Tingidae). The species usually feed on ornamental plants, but if they fall on people, during probing, they can bite. A historical example for Italy is the abundant presence on Platanus spp. of Corythucha ciliata Say.

\section{Italian situation on invasive species}

Within the Research Project of European Commission DAISIE (www.europe-aliens.org), an inventory of alien species in Europe was taken. Among introduced organisms, terrestrial invertebrates, mostly insects, represent the major cases of exotic introductions (Roques et al., 2009). Concerning Italy, 425 species of insects and 22 mites were recorded from 1492 to 2006 (Jucker et al., 2007, 2009; Pellizzari \& Dalla Montà, 1997; Pellizzari \& Faccoli, 2007). In our analysis we considered the species detected in Italy as exotic pests introduced by human activities or by passive transport from other countries, starting from 1945. We did not count insects that are naturally spreading in different Italian regions (e.g. as a result of the global warming process). The list was made after an examination of different material, mostly published in scientific journals and the EPPO website. We considered the species as being of agricultural, forest, or human importance for their different impact. Species introduced as biological control or species of stored products were not counted. The year of publication was considered as the same of that of detection; we have to point out, however, that in many cases the arrival could have happened some years before the official report, because most introductions occur unintentionally. A total of 291 exotic insects have been listed.

\subsection{Country of origin}

The native area of each species was taken from the publication of the interception. For our purposes, the world area was divided as follows: Africa (excluding Mediterranean Basin countries), Asia, Australia, North America, Central and South America, Mediterranean Basin, Europe (excluding Mediterranean Basin countries), and Pacific Islands (Australia not included). When the origin was not sure, as the case of many cosmopolitan species, we reported it as unknown (Fig. 1).

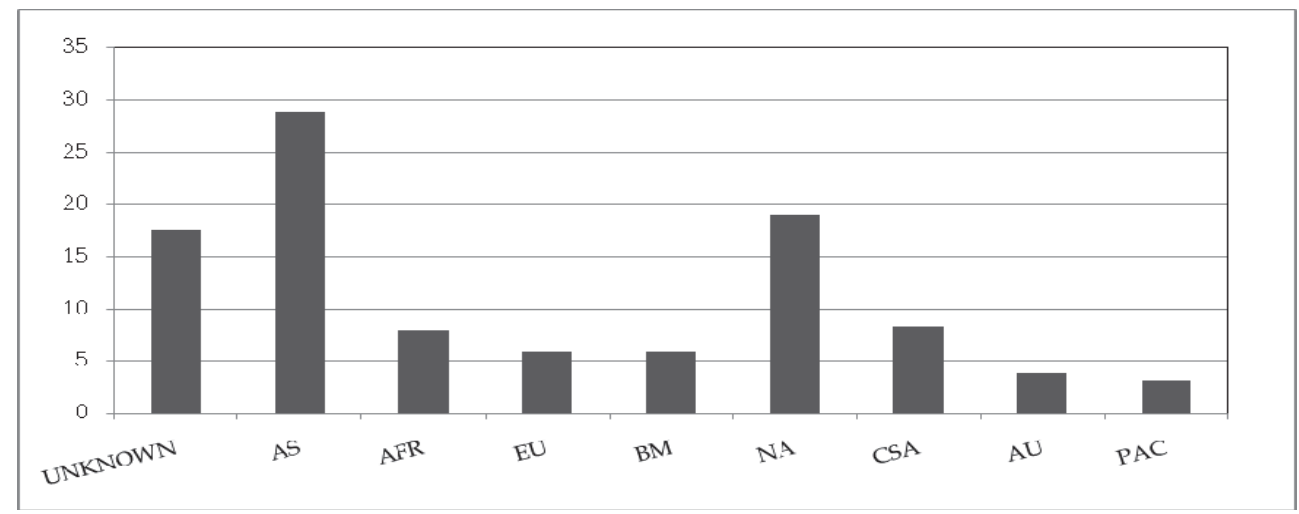

Fig. 1. Original country of the alien species in Italy. AS, Asia; AFR, Africa (excluding Mediterranean Basin countries); EU, Europe; BM, Mediterranean Basin countries; NA, North America; CSA, Central-South America; AU, Australia; PAC, Pacific Islands. 
Asia accounts for the largest proportion of Italian alien species $(28.9 \%)$, followed by North America $(19.0 \%)$. In many cases $(17.5 \%)$ the country of origin is unknown. Next, in order of decreasing importance, come the Central-South American countries (8.2\%), Africa (7.9\%), and European countries, in particular from the East $(5.8 \%)$ and Mediterranean Basin countries (5.8\%). Australia and other Pacific islands together represent $6.9 \%$. In addition, the proportion of the species coming from Asia and North America over the last 30 years represents $47.9 \%$ of the total.

Figure 2 illustrates the temporal evolutions of the detections of non-indigenous arthropods, with the data organized in decades (apart the first 15 years 1945-1960). The findings of alien species starts to increase significantly from 1980, and the highest number of new records was in the decade 1991-2000, with 111 species. In the last 10 years the number of new introductions has only slightly decreased. Considering our data, the rate of introduction increased from an average of 2.3 species/year until 1990 to an average of 9.9 species/year in the last 20 years.

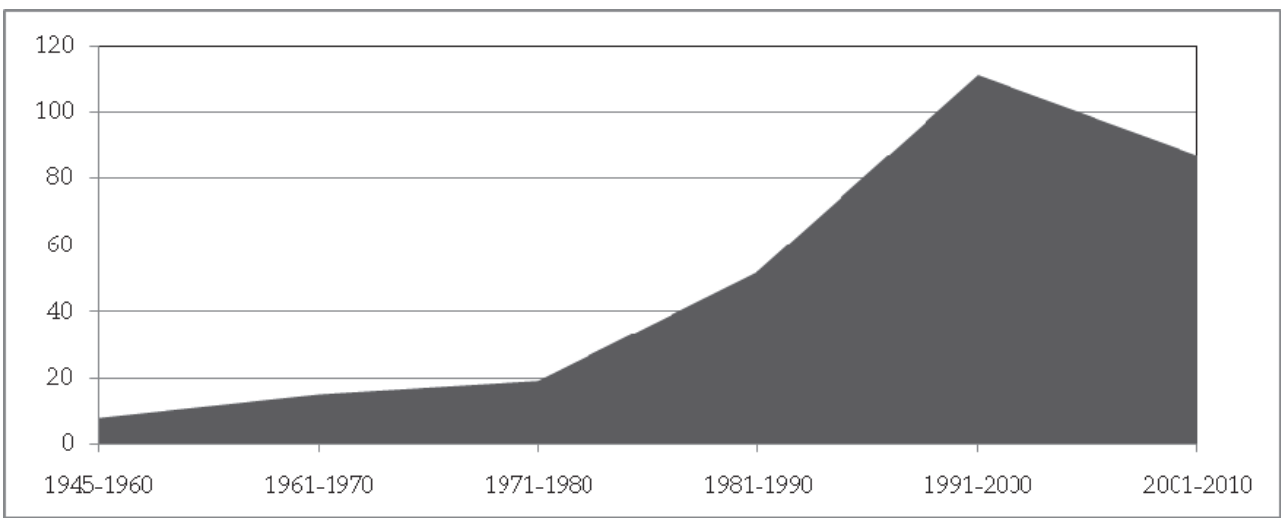

Fig. 2. Trend of non-indigenous species recorded in Italy in the recent decades.

\subsection{Taxonomy}

In the Figure 3 the taxonomic groups of the exotic insects in Italy are represented. Detailed descriptions of exotic species in the different orders follow.

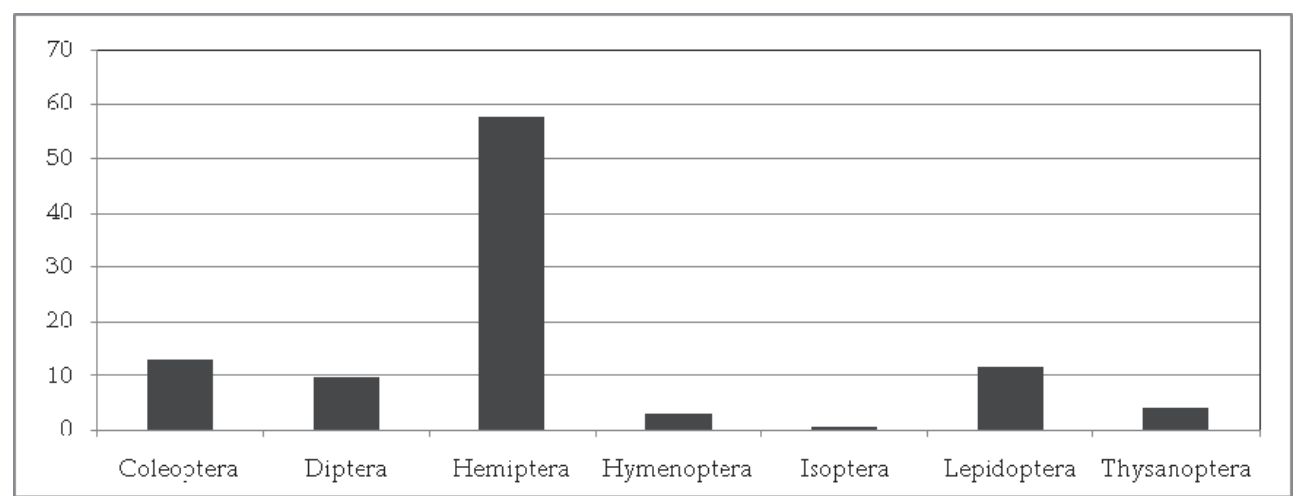

Fig. 3. Percentage of the orders introduced in Italy from 1945. 


\subsubsection{Hemiptera}

In our list of phytophagous insects, Hemiptera alone represent more than $57.7 \%$ of the total of the recorded species: $97 \%$ are Homoptera, while only $3 \%$ belong to Heteroptera. Members of this order (particularly psyllids, scales, aphids, and whiteflies) can easily escape during the phytosanitary controls because of their small size and their position, often hidden under the foliage, inside the flowers, or on the plant roots. They mostly come from Asia and North America, and many of them are of worldwide distribution, with the country of origin unclear. Considering the host, more than $50 \%$ attack woody plants, while $34 \%$ are phytophagous of various herbaceous plants. Only in a small number of cases the pathway of introduction well known. Because a lot of species are host-plant specific, in many cases they are introduced with the trade of their host plant. The major vector of the species in the new habitat is represented by ornamental woody plants. The psyllid Acizzia jamatonica (Kuwayama), native to Asia, was first recorded in Europe, in Italy, in 2002 (Alma et al., 2002). It was introduced in our country with its host plant, Albizia julibrissin, a plant species used in streets and in parking areas. Belonging to the same genus are A. acaciaebaileyanae (Froggatt) and A. uncatoides (Ferris \& Klyver), native to Australia and host of Acacia spp. and Albizia spp. Other examples of phytophagous insects on ornamental plants that are now widespread in our country are the two tyngids, Stephanitis takeyai Drake \& Maa from Japan, and S. pyrioides Scott from North America, both pests of Rhododendron spp. (Colombo \& Limonta, 2001b; Del Bene \& Pluot-Sigwalt, 2005). The same plant species can host the aphid Illinoia azaleae (Mason) and the whitefly Pealius azaleae (Baker \& Moles) (Del Bene et al.; 1991 Süss, 1973). The aphid Illinoia liriodendri (Monell) was found in Italy in 2001 (Limonta, 2001) on Liriodendron tulipifera, an exotic ornamental tree largely used for the color of its foliage and, in the past, for the absence of pests. Among scales affecting various ornamental woody plants mainly in gardens and urban parks, we refer to Ceroplastes japonicus Green (Kozar et al., 1984) and C. ceriferus (Fabricius) (Mori et al., 2001), both originating from Asia. Pulvinaria hydrangeae (Steinweden) is native to North America and its host is Tilia (Pellizzari, 1976). Recently, the red gum lerp psyllid Glycaspis brimblecombei Moore, attacking Eucalyptus camaldulensis in urban and rural landscapes, was reported (Laudonia \& Garonna, 2010). Corythucha ciliata and C. arcuata are two Heteroptera introduced to Italy from North America and living respectively on Platanus spp. and on Quercus spp. (Bernardinelli \& Zandigiacomo, 2000; Servadei, 1966). Two species with a high poliphagy are the well-known Metcalfa pruinosa and Acanalonia conica (Say) (D'Urso \& Uliana, 2004). They both live on wild and cultivated trees, shrubs, and grasses belonging to different families, some of which have an economic importance (Alma et al., 2005; Wilson \& McPherson, 1980).

Some Homoptera that damage forest plants are the scales Matsucoccus feytaudi Ducasse on Pinus pinaster and Marchalina hellenica Gennadius on pines (Arzone \& Vidano, 1981; Kozar et al., 1984). We can also add Gilletteella coweni (Gillette) on Douglas fir and Cinara cedri and C. laportei on Cedrus (Covassi, 1971; Covassi \& Binazzi, 1974, 1981). The western conifer seed bug Leptoglossus occidentalis is a serious pest of conifer seed production throughout western North America; economic damage consists in a reduction of the quantity and quality of seeds because of the trophic activity of adults and young instars sucking the seeds' endosperm. In Italy at the end of the 1990s the total weight of pine cones for pine nut production for food was about 40,000 tonnes per year. Since the introduction of the pest, production of pine nuts has rapidly decreased and in 2009 cone harvests from Italian stone pine forests declined by as much as $95 \%$ (Roversi et al., 2011). 
Herbaceous plants that host Hemiptera include graminaceae and various flowers; Tryonimus spp. and Antonina graminis Maskell are just some examples (Pellizzari, 1994).

Among fruits plants, Vitis vinifera had been seriously attacked since the 1960s by Scaphoideus titanus, and more recently by the leafhopper Erythroneura vulnerata Fitch (Duso et al., 2005). The latter pest is widespread in the United States and Canada where it has been reported as a pest of wild and cultivated grapes, and of other host plants. Up to now its occurrence in commercial vineyards is relatively unimportant, probably because of insecticide applications carried out during summer to control other pests. Many hemipteran pests of Citrus cultivation are found in Italy: Aonidiella citrina (Coquillett), Bemisia citricola Gomez Menor, Dialeurodes citri Ashmead, Aphis spiraecola Patch, Aleurothrixus floccosus Maskell, Chrysomphalus aonidum L., Unaspis yanonensis (Kuwana), and Aleurocanthus spiniferus Quaintance. The last one is a quarantine species, representing a serious risk to Italy.

\subsubsection{Coleoptera}

Non-indigenous Coleoptera (13.1\%) are mostly Cerambycidae, Chrysomelidae, Curculionidae, and Scolytidae. Asia and America have contributed the most non-indigenous Coleoptera, with more than $65 \%$ together, followed by Australia and the Pacific islands. Africa and Europe are of secondary importance.

Some alien beetles settled easily in our country, becoming agricultural pests. Omitting the well-acclimatized Leptinotarsa decemlineata Say, found in Italy in 1945, we want to focus on Diabrotica virgifera virgifera (LeConte), the northern corn rootworm from Central America, detected in 1992 near the Belgrade International Airport (Bača, 1994). The species, considered the major pest of maize in North America, settled in the new colonized area and now is present in 19 European countries. The chrysomelid arrived in Italy in 1998 and now occupies all the maize area in northern and central Italy. Its arrival in new countries can be attributed to aircraft; Miller et al. (2005) demonstrated that the pest has been introduced in Europe at least three times. Economic damage in Italy was observed in 2001 on only a few maize hectares (Boriani et al., 2002). More recently, the rice water weevil Lissorhoptrus oryzophilus was recorded in northern Italy (Caldara et al., 2004), but because this finding accidentally occurred during faunistic studies in the litter in Ticino Park (Lombardy), it was impossible to acquire information on the pathway of introduction of the insect (Lupi et al., 2010). Besides, until the rice water weevil detection, there were only a few arthropod species related to rice cultivation in Italy, with few outbreaks and little damage (Süss et al., 2008).

Among the exotic beetles that damage ornamental plants, some are extremely harmful and are listed as quarantine species. Among the most dangerous species of wooden plants worldwide we have to report Anoplophora chinensis and A. glabripennis (Motschulski), native to the Far East and detected in Italy in 2000 and in 2007, respectively (Colombo \& Limonta, 2001a; Maspero et al., 2007). The first one has acclimatized in our country and is spreading to the north despite the eradication program. A single infestation has also been present in Rome from 2008. A. glabripennis seemed to be eradicated in the first area but in 2009 a new report was made in Veneto Region (EPPO, 2011). A. chinensis was introduced with living trees, while $A$. glabripennis was found in the backyard of a private company that imports valves, and other metallic parts in wood packaging material from China. They are both xylophagous species that damage many broad-leaf plants. The high rate of polyphagy of these species increases the possibility of the pest spreading, making eradication more difficult. Up to now in Italy for the eradication of $A$. chinensis more than 18,000 plants have been removed and the cost of the 
eradication program has amounted to about 12 million euros. Originating from Asia, the red palm weevil, Rhynchophorus ferrugineus, is now threatening palms in public and private villas, historical gardens, roads and squares with inestimable environmental and cultural value (in particular Phoenix canariensis, $P$. dactylifera and Washingtonia robusta), spreading in all Italian regions where palms are grown (Sacchetti et al., 2005). Because of the low efficacy of control methods, all infested plants are cut and removed. Megaplatypus mutatus Chapuis, polyphagous on broad-leaf species, can compromise the stability of plants. Coming from South America, it is considered a quarantine species. In Italy serious damage has been recorded on Populus sp. (Tremblay et al., 2000).

Not included among quarantine pests but considered by EPPO as a potential threat and thus included in the Alert List is the Asiatic xylophagous Psacothea hilaris (Pascoe), a pest of fig and mulberry trees. Detected in 2005, it has shown how dangerous it can be by killing infested plants in the area where it has settled (Jucker et al., 2006). Its bio-ethology in the new habitat is still under study. Another Asiatic exotic insect threatening Ficus carica is Aclees spp., found in 2005 in a nursery. Larvae bore tunnels at the base of the trunk and in the roots, compromising the health of the plants (Ciampolini et al., 2005). Some other xylophagous pests of ornamental and forest plants introduced into Italy are the cerambycid Xylotrechus stebbingi Gahan from North America, the two Scolytidae Xylosandrus crassiusculus (Motsculsky) from the Pacific islands and Phloeotribus liminaris (Harris) from North America (Dioli \& Viganò, 1990; Pennacchio et al., 2003, 2004). Phoracantha semipunctata Fabricius, Phoracantha recurva (Newman), and Gonipterus scutellatus Gyllenhal are three pests of Eucalyptus native to Australia, introduced with infested wooden material (Arzone, 1976; Sama \& Bocchini, 2003; Tassi, 1970). All these species, which affect different plants, have not shown a particular impact on our environment yet, but they represent further records among the numerous introductions in our country.

\subsubsection{Lepidoptera}

Lepidoptera represent $11.7 \%$ of the alien species in Italy; $30 \%$ come from Asia, $23 \%$ are native to America (North and Central-South), and 20\% are of unknown origin. Others are European or African species.

In this order some species that cause serious economic damage are accounted. We refer, for example, to the Geranium Bronze Cacyreus marshalli (Butler), one of the most harmful insect pests of cultivated Geranium and Pelargonium. Native to South Africa, it was recorded in 1996 in central Italy and is now widespread (Trematerra et al., 1997; Lupi \& Jucker, 2004). In 2002 Paysandisia archon (Burmeister), a palm tree pest native to South America, was found in southern Italy and easily settled in our country (Espinosa et al., 2003). This is the only exotic castniid known in Europe, and it is present in almost all Mediterranean coasts. In Europe the species has been found on several palms. Originally feeding on Trithrinax campestris, the species in Europe has switched from the host plants to Phoenix canariensis, Latania sp. and on the only native European palm, Chamaerops humilis (Montagud, 2004). In Italy Chamaerops humilis, Trachycarpus fortunei, Phoenix canariensis, and Washingtonia represent the hosts. The tomato leaf borer Tuta absoluta (Meyrick), counted in the EPPO A2 list of quarantine pests, was found in Italy in 2008 and has shown itself to be very aggressive on different Solanaceae, especially tomatoes (Viggiani et al., 2009).

Cameraria ohridella Deschka \& Dimic, Phillonorycter robiniellus Clemens, Parectopa robiniella Clemens, Phyllocnistis citrella Stainton, and P. vitegenella Clemens are exotic leaf miners 
belonging to the family Gracillariidae, attacking woody plants. In particular, C. ohridella (Butin \& Fuhrer, 1994) causes aesthetic damage through larval trophic activity. Host trees (Aesculus hippocastanum) rarely die, but can be completely defoliated in the middle of summer. Moreover, recent studies suggest that $C$. ohridella could have a potential negative impact on native leaf miners via apparent competition and could also represent a risk for Acer pseudoplatanus in some areas (Péré et al., 2010).

\subsubsection{Diptera}

Diptera are $9.6 \%$ of all the arthropods introduced in Italy, and species in the family Agromyzidae and Cecydomyiidae predominate. Horticultural and ornamental trade represents the most important pathway of introduction. Most of the species are of unknown origin (53.5\%); others come essentially from North America, followed by Asia and CentralSouth America. Although they represent less than $10 \%$ of the introduced exotic insects, they include pest of economic importance.

The quarantine leafminers Agromizydae Liriomyza trifolii L. and L. huidobrensis Blanchard, coming respectively from North America and from Central-South America, caused much economic damage in the greenhouse cultivation of flowers and in general horticultural crops (Arzone, 1979; Süss, 1992).

Some species affect ornamental plants. The honeylocust gall midge Obolodiplosis robiniae (Haldeman) is strictly specific to Robinia pseudacacia. Detected in northern Italy in 2002, it is now present throughout the country (Bella, 2007). Cecydomia gleditchiae (Osten Sacken) cause galls on leaflets of Gleditsia triacanthos, while Phytoliriomyza jacarandae Steyskal \& Spencer is the leafminer of Jacaranda mimosifolia (Bella et al., 2007; Bolchi \& Volontè, 1984). Because of the species they attack and their monophagy, the importance of these pests is minimized to aesthetic damage, particularly in the area where these tree species are planted.

Rhagoletis completa Cresson represents an economically important pest of Juglans regia in the United States, especially in California. The species was recorded in Italy in 1991 (Duso, 1991) on some plants in the west of the country and could represent a serious threat to this tree and eventually to peach, known to be another host plant.

A species with economic importance is the newly introduced Drosophilidae Drosophila suzukii (Matsumura). Coming from the Far East, the species was recently recorded in North America and in Europe as noxious on strawberries, raspberries and other Rubus, blueberries, sweet cherries, plums, and many others fruit crops (EPPO, 2011). The dissemination of the pest over long distances is assured both by plants for planting and fruits. In Italy the species was detected in 2009 in the province of Trento (Grassi et al., 2009) and today represents a serious risk for many fruit crops with possible economic damage; D. suzukii was added to the Alert list in 2010 (EPPO, 2011).

Among diptera affecting humans we have to remember the mentioned Stegomyia albopicta.

\subsubsection{Thysanoptera}

Alien thrips (4.1\%) are native to Asia, North and Central-South America, Australia, and the Pacific islands. Because of their size and the part of plants infested, they are mostly transferred through trade in ornamental greenhouse plants; in fact, this tropical species can easily establish inside greenhouses.

Frankliniella occidentalis (Perg.) is considered one of the major worldwide crop pests, listed within the quarantine species producing high economic damage to different crops. Detected 
in Italy in 1987, it has represented a serious problem in glasshouses, both for direct and indirect damage, since the 1990s (Arzone et al., 1989). In 1998 a massive infestation of Echinothrips americanus Morgan (Scarpelli \& Bosio, 1999) was found in a heated greenhouse. This is a polyphagous species that can affect plants in glasshouses. Coming from America, it was probably introduced with ornamentals plants for planting. Another thrips on ornamentals in glasshouses is Bradinothrips musae (Hood), detected in 1999 in Lombardy on Spatiphyllum sp. and Musa sp. (Colombo et al., 1999). Pezothrips kellyanus (Bagnall), originally from Australia (Conti, 2001), was found on Citrus in 1998. This thrips can also attack Jasmimum fruticans, Pittosporum tobira, and Lonicera spp.

Thrips palmi Karny is a quarantine polyphagous pest, especially of Cucurbitaceae and Solanaceae, and represents a serious threat to numerous crops worldwide. Native to Asia, several interceptions have been reported, especially on cut flowers (mainly orchids) imported from Thailand, but up to now no settlement is known in Europe (Marullo, 1997).

\subsubsection{Hymenoptera}

Hymenoptera exotic species in Italy are mostly beneficials used as biological control agents. Pests in this order are few, representing $3.1 \%$ of the alien species. Belonging to the Eulophidae family and associated with Eucalyptus spp. are the species Lectocybe invasa Fisher \& La Salle, Ophelimus maskelli Ashmead, and Leprosa milga Kim \& La Salle; they are native to Australia and the Pacific islands and probably have been introduced with the host plant.

In 2002, the Hymenoptera Cinipidae Dryocosmus kuriphilus Yasumatzu, considered to be the most important pest of chestnut worldwide, was detected for the first time in Europe (in Piedmont, Italy) (Melika et al., 2002). From its first detection the pest rapidly expanded its colonization and now is present in quite the entire country, threatening chestnut production and Castanea trees, largely cultivated in some Italian regions. This quarantine species arrived with material for grafting.

Moreover, some exotic ants, mostly of tropical or subtropical origin, were recorded as new for the Italian fauna (Jucker et al., 2008). Because of their small size and their ability to nest in different materials, ants can easily be transferred by humans. Many species are found in glasshouses (e.g., Pheidole megacephala (Fabricius), P. nodus Smith, and Tetramorium bicarinatum) (Limonta \& Colombo, 2003) or indoors in heated buildings. Among exotic ants, we include the well-known Argentine ant Linepithema humile (Mayr) and the pharaoh ant Monomorium pharaonis (Linnaeus). Considered as anthropic pests, they are mostly present in buildings. At present, if we exclude the Argentine ant, most of these non-indigenous ants seem harmless to environments and humans.

\subsubsection{Isoptera}

Among Isoptera $(0.7 \%)$, the presence of Cryptotermis brevis (Walker), native to Central America, was recorded in 1994 (Tremblay \& Priore, 1997). The species was first found in the South of Italy, but afterwards other findings were made in Palermo and in northern Italy (Raineri et al., 2001). Further interception was made in 2003, when an infestation of adults belonging to the Coptotermes genus was found on a boat in Naples harbor. These termites add to the other species of Isoptera still present in our country (Kalotermes flavicollis F. and Reticulitermis lucifugus (Rossi) (Savoldelli \& Lupi, 2008).

\subsection{Pathways}

Beyond the natural spreading of species, most alien insects are accidentally transferred across countries through passive transport arising from commercial activities and human 
movement. Many interceptions occur on live wooden plants, mostly ornamental plants, considering the entire plant or just part of it. The import of bonsais has recently been receiving more and more attention for the introduction of alien insects, such as Anoplophora chinensis and numerous Homoptera (e.g. Neophyllaphis podocarpi Takahashi, Lopholeucaspis japonica (Cockerell), Rhizoecus hibisci Kawai \& Takagi, and Tinocallis ulmiparvifoliae Matsumura). Wood packaging material and timber in general are associated with Coleoptera, in particular xylophagous, and Isoptera. Recently, some harmful cerambycids were imported on those goods, e.g. Anoplophora glabripennis, Psacothea hilaris, and Megaplatypus mutatus. Anoplophora chinensis is also known to be transported on pallets.

Notwithstanding phytosanitary regulations, these cryptic species can easily escape control because they live most of their biological cycle hidden inside the wood. Moreover, up to now effective detection methods do not exist, even though researchers are studying various techniques (e.g. acoustic methods, ultrasound, x-rays, tomography, infrared thermo imaging, detection dogs). Species are often transported inside living plants or wooden material without any observable symptoms outside. Only when the pests are in the new area and the environmental conditions are suitable do they emerge, causing much damage. Where living plants are concerned, horticultural and ornamental trade is probably the most significant pathway. Larvae of leaf miners can easily hide inside leaves or fruits (e.g. Liriomyza spp., Rhagoletis completa), as for the gall midge. Cut flowers, plant materials for propagation, and seeds are also known to carry pests (Liriomyza trifolii, Dryocosmus kuriphilus, Frankliniella occidentalis, etc.).

Means of transport also represent a possible pathway of entrance of exotic insects. The introduction of Aedes albopictus in Italy from the United States is ascribed to the trade of secondhand tires, where females lay eggs; moreover, larvae of A. albopictus were found inside bags watering "lucky bamboos" (Dracaena senderiana). Diffusion over short distances can be attributed to cars or trucks. The spreading of Cameraria ohridella inside Europe can also be ascribed to land transport. The arrival of D. virgifera virgifera in Europe, near the Belgrade airport, can be attributed to transfer by plane. Afterwards, many other new findings in different European countries were made close to airport areas by plane, as well the introduction of Metcalfa pruinosa.

Intentional introductions represent a high percentage of the species in some orders, like Hymenoptera and some Diptera, due to the large number of species introduced as biological control agents, which is not considered in our work.

\section{Conclusion}

The introduction of exotic arthropods is a dynamic non-stop process with new species reported each year. Insects probably represent the taxon with the most numerous exotic species in Italy. The history of new introductions in our country is similar to that in other parts of the world. The increasing globalization of trade and people can raise this trend with new interceptions every day, especially in industrialized countries with a high level of commercial exchanges. Moreover, the global warming phenomenon can enhance the risk of some species - particularly of tropical or subtropical origin - settling in the Mediterranean area, allowing them to spread in the new colonized area. Moreover, many Italian exotic species are listed among the 100 most invasive species in Europe (e.g. Anoplophora chinensis, A. glabripennis, Stegomyia albopicta, Diabrotica virgifera virgifera, Harmonia axyridis), and in many cases they have been recorded in our country for the first time in Europe, confirming that Italy is at high risk of introduction. 


\section{Acknowledgment}

This research was supported by the University of Milan Research Project "Unimi 5permille: RISEKO" and was developed within the Research Projects financed by Lombardy Region and MiPAAF (Agricultural, Alimentary and Forestry Ministry).

The authors are grateful to all their colleagues that made these researches possible and in particular to our Professor Mario Colombo for his support, and to Prof. Lidia Limonta and F. Romana Eördegh for their useful comments.

\section{References}

Aebi, A.; Schönrogge, K.; Melika, G.; Quacchia, A.; Alma, A. \& Stone, G.N. (2007). Native and introduced parasitoids attacking the invasive chestnut gall wasp Dryocosmus kuriphilus. EPPO Bulletin, Vol. 37, No. 1, (April 2007), pp. 166-171, ISSN 1365-2338

Albright, D.D.; Jordan-Wagner, D.; Napoli, D.C.; Parker, A.L.; Quance-Fitch, F.; Whisman, B.; Collins, J.W. \& Hagan, L.L. (2006). Multicolored Asian lady beetle hypersensitivity: a case series and allergist survey. Annals of Allergy, Asthma $\mathcal{E}$ Immunology, Vol. 97, No. 4, (October 2006), pp. 521-527, ISSN 1081-1206.

Alma, A.; Tedeschi, R. \& Rossi, J. (2002). Acizzia jamatonica (Kuwayama) nuova psilla per l'Europa (Homoptera Psillidae). Informatore Fitopatologico, Vol. 52, No. 4, (April 2002), pp. 64-65, ISSN 0020-0735

Alma, A.; Ferracini, C. \& Burgio, G. (2005). Development of a Sequential Plan to Evaluate Neodryinus typhlocybae (Ashmead) (Hymenoptera: Dryinidae) Population Associated with Metcalfa pruinosa (Say) (Homoptera: Flatidae) Infestation in Northwestern Italy. Environmental Entomology, Vol. 34, No. 4, (August 2005), pp. 819-824, ISSN 0046-225X

Alyokhin, A. \& Sewell, G. (2004). Changes in A Lady Beetle Community Following the Establishment of Three Alien Species. Biological Invasions, Vol. 6, No. 4, (December 2004), pp. 463-471, ISSN 1387-3547

Angelini, E.; Clair, D.; Borgo, M.; Bertaccini, A. \& Boudonpadieu, E. (2001). Flavescence Dorée in France and Italy: occurrence of closely related Phytoplasma isolates and their near relationships to Palatinate grapevine yellows and an alder yellows phytoplasma. Vitis, Vol. 40, No. 2, (June 2001), pp. 79-86, ISSN 0042-7500

Angelini, R.; Finarelli, A.C.; Angelini, P.; Po, C.; Petropulacos, K.; Macini, P.; et al. (2007). An outbreak of chikungunya fever in the province of Ravenna, Italy. In: Eurosurveillance, Vol. 12, No. 36, Art. 3260, 17.03.2011, Available from: http://www.eurosurveillance.org

Arzone, A. (1976). Un nemico dell'Eucalipto nuovo per l'Italia. L'Apicoltore Moderno, Vol. 67, No. 6, (November-December 1976), pp. 173-177, ISSN 0518-1259

Arzone, A. (1979). L'agromizide neartico Liriomyza trifolii (Burgess) nuovo nemico di Gerbera in Italia. Informatore Fitopatologico, Vol. 29, No. 3, (March 1979), pp. 3-6, ISSN 0020-0735

Arzone, A. \& Vidano, C. (1981). Matsucoccus feytaudi Due. (Homoptera, Margarodidae), fitomizo letale a Pinus pinaster Ait. in Italia. Informatore Fitopatologico, Vol. 31, No. 10, (October 1981), pp. 3-10, ISSN 0020-0735

Arzone, A.; Alma, A. \& Rapetti, S. (1989). Frankliniella occidentalis (Perg.) (Thysanoptera Thripidae) nuovo fitomizo delle serre in Italia. Informatore Fitopatologico, Vol. 39, No. 10, (October 1989), pp. 43-48, ISSN 0020-0735. 
Bača, F. (1994). New member of the harmful entomofauna of Yugoslavia, Diabrotica virgifera virgifera virgifera LeConte (Coleoptera, Chrysomelidae). Zastita Bilja, Vol. 45, No. 2, pp. 125-131, ISSN 0372-7866

Bazzocchi, G.; Lanzoni, A.; Accinelli, G. \& Burgio, G. (2004). Overwintering, phenology and fecundity of Harmonia axyridis in comparison with native coccinellid species in Italy. BioControl 49, (June 2004), pp. 245-260, ISSN 1386-6141

Bella, S. (2007). Presenza di Obolodiplosis robiniae (Haldeman, 1847) in Italia centromeridionale e in Sicilia (Diptera Cecidomyiidae). Bollettino di Zoologia Agraria e di Bachicoltura Ser. II, Vol. 39, No. (3), (December 2007), pp. 239-242, ISSN 0366-2403

Bella, S.; Mazzeo, G. \& Süss, L. (2007). First record for the European fauna of Phytoliriomyza jacaranda Steyskal \& Spencer, 1978 (Diptera Agromyzidae) leafminer of Jacaranda mimosifolia D. Don. (Bigoniaceae). Bollettino di Zoologia agraria e di Bachicoltura. Ser. II, Vol. 39, No. 1, (April 2007), pp. 75-78. ISSN 0366-2403

Bernardinelli, I. \& Zandigiacomo, P. (2000). Prima segnalazione di Corythucha arcuata Say (Heteroptera: Tingidae) in Europa. Informatore Fitopatologico, Vol. 50, No. 12, (December 2000), pp. 47-49, ISSN 0020-0735

Bolchi, G. \& Volontè, L. (1984-1985). Dasineura gleditchiae (Osten Sacken), cecidomide nuovo per l'Italia (Diptera Cecidomyiidae). Bollettino di Zoologia Agraria e di Bachicoltura Ser. II, Vol. 18, No. 2, (December 1985), pp. 185-189, ISSN 0366-2403

Boriani, M.; Bettoni, D. \& Notarangelo, N. (2002). Primi danni da Diabrotica su mais in Italia. L'Informatore Agrario, Vol. 28, No. 31, (July 2002), pp. 61-62, ISSN 0020-0689

Brittlebank, C.C. (1919). Tomato diseases. Agricultural journal of Victoria, Vol. 27, pp. 231-235

Brussino, G.; Bosio, G.; Baudino, M.; Giordano, R.; Ramello, F. \& Melika, G. (2002). Pericoloso insetto esotico per il castagno europeo. L'Informatore agrario. Vol. 28, No. 37, (September 2002), pp. 59-61, ISSN 0020-0689

Burgio, G.; Lanzoni, A.; Accinelli, G. \& Maini, S. (2008). Estimation of mortality by entomophages on exotic Harmonia axyridis versus native Adalia bipunctata in semifield conditions in northern Italy. BioControl, Vol. 53, No (1), (February, 2008), pp. 277-287, ISSN 1386-6141

Butin, H. \& Fuhrer, E. (1994). The horse-chestnut miner (Cameraria ohridella Deschka \& Dimic), a new pest of Aesculus ippocastanum. Nachrichtenblatt des Deutschen pflanzenschutzdienstes, Vol. 46, No. 5, pp. 89-91, ISSN:00277479

Caldara, R.; Diotti, L. \& Regalin R., (2004). First record for Europe of the rice water weevil, Lissorhoptrus oryzophilus Kuschel (Coleoptera, Erirhinidae). Bollettino di Zoologia Agraria e di Bachicoltura Ser. II, Vol. 36, No. 1, (April 2004), pp. 165-171, ISSN 03362403

Chen, H.; Chen, Z.M. \& Zhou, Y.S. (2005). Rice water weevil (Coleoptera: Curculionidae) in mainland China: invasion, spread and control. Crop Protection, Vol. (24), No. (8), (August 2005), pp. 695-702, ISSN 0261-2194

Ciampolini, M.; Regalin, R. \& Peerin, H. (2005). Aclees cribratus, nuovo per l'Italia nocivo al fico allevato in vivaio. L'Informatore agrario, Vol. 61, No. 47, (December 2005), pp. 69-71, ISSN 0020-0689

Ciosi, M.; Miller, N. J.; Toepfer, S.; Estoup, A. \& Guillemaud, T. (2011). Stratified dispersal and increasing genetic variation during the invasion of Central Europe by the western corn rootworm, Diabrotica virgifera virgifera. Evolutionary Applications, Vol. 4, No. 1, (January 2011), pp. 54-70, ISSN 1752-4571

Colombo, M.; Rigamonti, I.E. \& Eördegh, F.R. (1999). Segnalazione di Bradinothrips musae (Hood) (Thysanoptera Thripidae) in una serra della Lombardia. Bollettino di 
Zoologia Agraria e di Bachicoltura, Ser II, Vol. 31, No. 2, (August 1999), pp. 231-234, ISSN 0336-2403

Colombo, M. \& Limonta, L. (2001)a. Anoplophora malasiaca Thomson (Coleoptera Cerambycidae Lamiinae Lamiini) in Europe. Bollettino di Zoologia Agraria e di Bachicoltura, ser II, Vol. 33, No. 2, (August 2001), pp. 65-68, ISSN 0336-2403

Colombo, M. \& Limonta, L. (2001)b. Presenza di Stephanitis takeyai Drake e Maa (Heteroptera Tingidae) su Pieris japonica (Thunb.) introdotta in Italia. Bollettino di Zoologia Agraria e di Bachicoltura, Ser II, Vol. 33, No. 1, (April 2001), pp. 139-142, ISSN 0336-2403

COM (2008). Towards an eu strategy on invasive. In: Communication from the commission to the council, the european parliament, the european economic and social committee and the committee of the regions. Commission of the European Communities 789 Final, Available from:

http:/ /ec.europa.eu/environment/nature/invasivealien/docs/1_EN_ACT_part1_ v6.pdf

Conti, B. (2001). Segnalazioni Faunistiche Italiane, N 394. Bollettino della Società Entomologica Italiana, Vol. 133, No. 3, pp. 267-272, ISSN 0373-3491

Covassi, M. (1971). Osservazioni preliminari sulla presenza in Italia di un afide nocivo ai cedri: Cedrobium laportei Remaud (Homoptera, Lachnidae). Redia, Vol. 52, pp. 641652, ISSN 0370-4327

Covassi, M. \& Binazzi, A. (1974). Note corologiche e morfologiche sulla Cynara cedri Mim. in Italia (Homoptera, Lachnidae). Redia, Vol. 55, pp. 331-341, ISSN 0370-4327

Covassi, M. \& Binazzi, A. (1981). Contributi alla conoscenza degli Afidi delle Conifere. IV, Note su alcune specie di Adelgidi reperite in Italia (Homoptera Adelgidae). Redia, Vol. 64, pp. 303-329, ISSN 0370-4327

Dalla Pozza, G. \& Majori, G. (1992). First record of Aedes albopictus establishment in Italy. Journal of the American Mosquito Control Association, Vol. 8, No. 3, (September 1992), pp. 318-320. ISSN 8756-971X

Del Bene, G.; Gargani, E. \& Landi, S. (1991). Note su Pealius azaleae (Baker et Moles) (Hom. Aleyrodidae) specie nuova per l'Italia. Redia, Vol. 74, pp. 163-175, ISSN 0370-4327

Del Bene, G. \& Pluot-Sigwalt ,D. (2005). Stephanitis pyrioides (Scott) (Heteroptera Tingidae): a lace bug new to Italy. Bollettino di Zoologia Agraria e di Bachicoltura Ser II, Vol. 37, No. 1, (April 2005), pp. 71-76, ISSN 0336-2403

Delvare, G.; Bon, Mc.; Hérard, F.; Cocquempot, C.; Maspero, M. \& Colombo, M. (2004). Description of Aprostocetus anoplophorae n. sp. (Hymenoptera: Eulophidae), a new egg parasitoid of the invasive pest Anoplophora chinensis (Förster) (Coleoptera: Cerambycidae). Annales Société Entomologique de France (N. S.), Vol. 40, No. 3-4, (August 2005), pp. 227-233, ISSN 0037-9271

Deschka, G. \& Dimic., N. (1986). Cameraria ohridella sp. n. (Lep., Lithocolletidae) aus Mazedonien, Jugoslawien. Acta entomologica jugoslavica, Vol. 22, No. 1-2, pp. 11-23, ISSN 0350-5510

Dindo, M.L.; Francati, S.; Marchetti, E.; Lanzoni, A.; Maini, S.; Jucker, C. \& Lupi, D. (2011). New associations between native parasitoids and two exotic insects introduced in Italy. Proceedings of the Second Entomophagous Insects Conference, Antibes France, 2023 June 2011, in press

Dioli, P. \& Viganò, C. (1990). Presenza in Valtellina di un cerambice nuovo per la Fauna italiana: Xylotrechus stebbingi Gahan, 1906. (Insecta, Coleoptera, Cerambycidae). Il Naturalista Valtellinese, Vol. 1, pp. 7-10, ISSN 1120-6519 
D'Urso, V. \& Uliana, M. (2004). First record of Acanalonia conica (Issidae) in Italy. Proceeding of third European Hemiptera Congress, Saint Petersburg, Russia, 8-11 June 2004

Duso, C. (1991). Sulla comparsa in Italia di un Tefritide neartico del noce: Rhagoletis completa Cresson (Diptera: Tephritidae). Bollettino di Zoologia Agraria e di Bachicoltura, Ser II, Vol. 23, No. 2, (August 1991), pp. 203-209, ISSN 0336-2403

Duso, C.; Bressan, A.; Mazzon, L. \& Girolami, V. (2005). First record of the grape leafhopper Erythroneura vulnerata Fitch (Hom., Cicadellidae) in Europe. Journal of Applied Entomology, Vol. 129, No. 3, (April 2005), pp. 170-172, ISSN 1439-0418

EPPO (2011). European and plant protection organization. 10.03.2011, Available from: http://www.eppo.org

Eritja, R.; Escosa R.; Lucientes, J.; Marquès, E.; Molina, R.; Roiz, D. \& Ruiz, S. (2005). Worldwide invasion of vector mosquitoes: present European distribution and challenges for Spain. Biological Invasions, Vol. 7, No. 1, (March 2005), pp. 87-97, ISSN 1387-3547

Espinosa, B.; Muccio, P. \& Di Russo, G. (2003). Paysandisia archon, una minaccia per le nostre palme. L'Informatore Agrario, Vol. 59, No. 7, (February 2003), pp. 61, ISSN 0020-0689

Gilbert, M.; Grégoire, J.C.; Freise, J.F. \& Heitland, W. (2004). Long-Distance Dispersal and Human Population Density Allow the Prediction of InvasivePatterns in the Horse Chestnut Leafminer Cameraria ohridella. Journal of Animal Ecology, Vol. 73, No. 3, (May 2004), pp. 459-46, ISSN 0021-8790

Giraud, T.; Pedersen, J.S. \& Keller, L. (2002). Evolution of supercolonies: The Argentine ants of southern Europe. PNAS, Vol. 99, No. 9, (April 2002), pp. 6075-6079, ISSN 00278424

Grabenweger, G.; Kehrli, P.; ller, I. Z.; Augustin, S.; Avtzis, N.; Bacher, S.; Freise, J.; et al. (2009). Temporal and spatial variations in the parasitoid complex of the horse chestnut leafminer during its invasion of Europe. Biological Invasions, Vol. 12, No. 8, (August 2010), pp. 2797-2813, ISSN 1387-3547

Grassi, A.; Calmieri, L. \& Giongo, L. (2009). Drosophila (Sophophora) suzukii (Matsumura). Nuovo fitofago per i piccoli frutti in Trentino. Terra Trentina, Vol. 54, No. 10, (November 2009), pp. 19-23

Gröbler, C. B. \& Lewis, O.T. (2008). Response of native parasitoids to a range-expanding host. Ecological Entomology, Vol. 33, No. 4, (August 2008), pp. 453-463, ISSN 03076946

Gullan, P.J \& Cranston, P.S. (2010). The insects: An outline of entomology. Blackwell Publishing, pp. 1- 559, ISBN 1444330365, Oxford UK

Haxaire, J.; Bouguet, J.P. \& Tamisier, J.P. (2006). Vespa velutina Lepeletier, 1836, une redoutable nouveauté pour la faune de France (Hym., Vespidae). Bulletin de la Société Entomologique de France, Vol. 111, No. 2, pp. 194, ISSN 0037-928X.

Heisey, R.M. (1990). Evidence for allelopathy by tree-of-heaven (Ailanthus altissima). Journal of Chemical Ecology,Vol. 16, No. 6, (June 1990), pp. 2039-2055, ISSN 0098-0331

Hérard, F.; Cocquempot, C.; Lopez, J.; Covi, J.; Maspero, M. \& Colombo, M. (2004). Field study to evaluate the egg parasitoid Aprostocetus anoplophorae sp. n. (Hymenoptera: Eulophidae) on two Anoplophora hosts. Proceedings, XV USDA Interagency Research Forum on Gypsy Moth and Other Invasive Species, Annapolis USA, 13-16 January 2004

Hoffmann, A.A.; Reynolds, K.T.; Nash, M.A. \& Weeks, A.R. (2011). A high incidence of parthenogenesis in agricultural pests. Proceeding Royal Society B., Vol. 278, (March 2011), pp. 799-800 ISSN 1364-5021 
Hoffmeister, T.S.; Vet, L.E.M.; Biere, A.; Holsinger, K. \& Filse, J. (2005). Ecological and Evolutionary Consequences of Biological Invasion and Habitat Fragmentation. Ecosystems, Vol. 8, No. 6, (September 2005), pp. 657-667, ISSN 1387-3547

Holway, D.A. (1998). Effect of Argentine ant invasions on ground-dwelling arthropods in northern California riparian woodlands. Oecologia, Vol. 116, No. 1-2, (August 1998), pp. 252-258, ISSN 0029-8549

Howarth, F.G. (1991). Environmental impacts of classical biological control. Annual Review of Entomology, Vol. 36, (January 1991), pp. 485-509, ISSN 0066-4170

Inoue, T. \& Sakurai, T. (2006). Infection of Tomato spotted wilt virus (TSWV) shortens the life span of thelytokous Thrips tabaci (Thysanoptera: Thripidae). Applied Entomology and Zoology, Vol. 41, No. 2, (June 2006), pp. 239-246, ISSN 0003-6862

Jucker, C.; Tantardini, A. \& Colombo, M. (2006). First record of Psacothea hilaris (Pascoe) (Coleoptera Cerambycidae Lamiinae Lamini) in Europe. Bollettino di Zoologia agraria e Bachicoltura Ser. II, Vol. 38, No. 2, (August 2006), pp. 187-191, ISSN 0336-2403

Jucker, C.; Maspero, M. \& Colombo, M. (2007). Principali fitofagi in ambiente urbano e loro contenimento. Informatore Fitopatologico Vol. 57, No. 7/8, (June 2007), pp. 22-25, ISSN 0020-0735

Jucker, C.; Quacchia, A.; Colombo, M. \& Alma, A. (2007). Hemiptera recently introduced into Italy. Bulletin of Insectology, Vol. 61, No. 1, pp. 145-146, ISSN 1586-4502

Jucker, C.; Valentini, M. \& Lupi, D. (2007). Intercettazioni di insetti esotici in Lombardia Proceedings XXI Congresso Nazionale Italiano di Entomologia pp.195, Campobasso Italy 11-16 June 2007

Jucker, C.; Rigato, F. \& Regalin, R. (2008). Exotic ant records from Italy (Hymenoptera, Formicidae). Bollettino di Zoologia agraria e Bachicoltura Ser. II, Vol. 40, No. 1, pp. 99107, ISSN 0336-2403

Jucker, C.; Barbagallo, S.; Roversi, P.F. \& Colombo, M. (eds.) (2009). Insetti esotici e tutela ambientali: morfologia, biologia, controllo e gestione, MiPAAF, Cermenate (CO), Italy

Kenis M, Auger-Rozenberg M-A, Roques A, Timms L, Péré C, Cock MJW, Settele J, et al. (2009.) Ecological effects of invasive alien insects. Biological Invasions 11: 21-45.

Kenis, M. \& Branco, M. (2010). Impact of alien terrestrial arthropods in Europe. BioRisk, Vol. 4, No. 1, (July 2010), pp. 51-71, ISSN 1313-2644

Kozar, F.; Tranfaglia, A. \& Pellizzari, G. (1984). New records on the scale insect fauna of Italy (Homoptera: Coccoidea). Bollettino del Laboratorio di Entomologia agraria "Filippo Silvestri", Vol. 41, pp. 3-10, ISSN: 0304-0658

Laudonia, S. \& Garonna, A.P. (2010). The red gum lerp psyllid, Glycaspis brimblecombei, a new exotic pest of Eucalyptus camaldulensis in Italy. Bulletin of Insectology, Vol. 63, No. 2, pp. 233-236, ISSN 1586-4502

Liebhold, A.M. \& Tobin, P.C. (2008). Population Ecology of Insect Invasions and Their Management. Annual Review of Entomology, Vol. 53, (January 2008), pp. 387-408, ISSN 0066-4170

Limonta, L. (2001). Heavy infestation of Illinoia liriodendri (Monell) (Rhynchota: Aphididae) in northern Italy. Bollettino di Zoologia Agraria e di Bachicoltura, Ser. II, Vol. 33, No. 2, (August 2001), pp. 133-136, ISSN 0336-2403

Limonta, L. \& Colombo, M. (2003). Record of Pheidole megacephala (F.), Pheidole nodus Smith and Tetramorium bicarinatum Nylander (Hymenoptera Formicidae), tropical species, in nursery imported plants. Bollettino di Zoologia Agraria e di Bachicoltura, Ser. II, Vol. 35, No. 2, (August 2003), pp. 287- 289, ISSN 0336-2403 
Linder, C.; Lorenzini, F. \& Kehrli, P. (2009). Potential impact of processed Harmonia axyridis on the taste of 'Chasselas' and 'Pinot noir' wines. Vitis , Vol. 48, No. 2, pp.101-102, ISSN 0042-7500

Longo, S. \& Tamburino, V. (2005). Gravi infestazioni di punteruolo rosso della palma. L'Informatore Agrario, Vol. 61, No. 50, (December 2005), pp. 73-74, ISSN 0020-0689

Lupi, D. \& Jucker, C. (2004). Il lepidottero Cacyreus marshalli minaccia le colture di geranio. Clamer informa, Vol. 29, No. 2, pp. 51-54, ISSN 0394-9435

Lupi, D. (2005). A three year field survey of the natural enemies of the horse-chestnut leaf miner Cameraria ohridella in Lombardy, Italy. BioControl, Vol. 50, No. 1, (February 2005), pp. 113-126, ISSN 1386-6141

Lupi, D.; Colombo, M.; Giudici, M.L.; Villa, B.; Sparacino, A.C. \& Ranghino, F. (2007). Present status of knowledge on Lissorhoptrus oryzophilus Kuschel (Rice Water Weevil) in Italy. Proceedings of the fourth temperate rice conference, pp. 138-139, ISBN 978-88-95616-01-8, Novara, Italy, 25-28 June 2007

Lupi, D.; Cenghialta, C. \& Colombo, M. (2009). Adult feeding by the rice water weevil Lissorhoptrus oryzophilus on different host plants. Bulletin of Insectology, Vol. 62, No. 2, pp. 229-236, ISSN 1586-4502

Lupi, D.; Giudici, M.L.; Cenghialta, C.; Villa, B.; Passoni, D. \& Colombo, M. (2010). On the spatial spread of the Rice water weevil, Lissorhoptrus oryzophilus Kuskel (Coleoptera: Erirhinidae), in Italy. Journal of Entomological and Acarological Research, Ser II, Vol. 42, No. 2, (August 2010), pp. 81-90, ISSN 2038-324X

Marullo, R. (1997). Thrips palmi, un importante parassita da quarantena per l'Italia. Informatore Fitopatologico, Vol. 47, No. 10, (October 1997), pp. 18-22, ISSN 0020-0735

Maspero, M.; Jucker, C. \& Colombo M. (2007). First record of Anoplophora glabripennis (Motschulsky) (Coleoptera Cerambycidae Lamiinae Lamiini) in Italy. Bollettino di Zoologia agraria e Bachicoltura, Ser II, Vol. 39, No. 2, (August 2007), pp. 161-164, ISSN 0336-2403

Maspero, M.; Cavalieri, G.; D’Angelo, G.; Jucker, C.; Valentini, M.; Colombo, M.; Hérard, F.; et al. (2007). Anoplophora chinensis - Eradication programme in Lombardia (Italy), 10.02.2011, Available from: http:/ / www.eppo.org.

Melika G.; Brussino, G.; Bosio, G. \& Csoka, G. (2002). Chestnut gall wasp (Dryocosmus kuriphilus Yamatzu), a new pest of chestnut in Europe. Növényvédelem, Vol. 39, No 2, pp. 59-63, ISSN 0133-0829

Michaud, J.P. (2002). Classical Biological Control: A Critical Review of Recent Programs Against Citrus Pests in Florida. Annals of the Entomological Society of America, Vol. 95, No. 5, (September 2002), pp. 531-540, ISSN 0013-8746

Miller, N.; Estoup, A.; Toepfer, S.; Bourguet, D.; Lapchin, L.; Derridj, S.; Kim, K. S.; Reynaud, P.; Furlan, L. \& Guillemaud, T. (2005). Multiple transatlantic introductions of the western corn rootworm. Science, Vol. 310, No. 5750, (November 2005), pp. 992, ISSN 0036-8075

Montagud, S. (2004). Paysandisia archon (Burmeister, 1880) (Lepidoptera, Castniidae), nuevas localizaciones en la Península Ibérica y su gestión. Boletín Sociedad Entomológica Aragonesa, Vol. 34, (April 2004), pp. 237-246, ISSN 1134-6094

Mori, N.; Pellizzari, G. \& Tosi, P. (2001). Ceroplastes ceriferus (Fabricius) (Hemiptera, Coccoidea): new pest of ornamentals in Europe? Bollettino di Zoologia Agraria e di Bachicoltura, Ser II, Vol. 33, No. 3, (December 2001), pp. 331-336, ISSN 0336-2403 
Moriya, S.; Shiga, M. \& Adachi, I. (2003). Classical biological control of the chestnut gall wasp in Japan, Proceedings of the 1st International Symposium on biological control of arthropods, pp. 407-415, Honolulu, Hawaii, 14-18 January 2002

Mota, M.M.; Braasch, H.; Bravo, M.A.;Penas, A.C.; Burgermeister, W.; Metge, K. \& Sousa, E. (1999). First report of Bursaphelenchus xylophilus in Portugal and in Europe. Nematology, Vol. 1, No. 7-8, (November 1999), pp. 727-734, ISSN 1388-5545

Pearson, D.E. \& Callaway, R.M. (2003). Indirect effects of host-specific biological control agents. Trends in Ecology and Evolution, Vol. 18, No. 9, (September 2003), pp. 456461, ISSN 0169-5347

Pellizzari, G. (1976). Sulla presenza in Italia dell'Eupulvinaria hydrangeae (Steinw.) (Homoptera, Coccoidea). Redia, Vol. 59, pp. 59-67, ISSN 0370-4327

Pellizzari, G. (1994). Homoptera, Coccoidea new for Italy. Bollettino di Zoologia Agraria e di Bachicoltura, Ser II, Vo. 26, No. 2, (August 1994), pp. 271-274, ISSN 0336-2403

Pellizzari, G. \& Dalla Montà, L. (1997). Gli insetti fitofagi introdotti in Italia dal 1945 al 1995. Informatore Fitopatologico, Vol. 47, No. 10, (October 1997), pp. 4-12, ISSN 0020-0735. 068

Pellizzari, G.; Dalla Montà, L. \& Vacante, V. (2005). Alien insect and mite pests introduced to Italy in sixty years (1945-2004). Proceeding of Plant protection and plant health in Europe: introduction and spread of invasive species, pp. 275-276, ISBN 1901396 819, Berlin, Germany, 9-11 June 2005

Pellizzari, G. \& Faccoli, M. (2007). Checklist degli acari e insetti introdotti in Italia dopo la scoperta dell'America. Proceeding of XXI Congresso Nazionale Italiano di Entomologia, pp. 64, Campobasso, Italy, 11-16 June 2007

Pennacchio, F.; Roversi, P.F.; Francardi, V. \& Gatti, E., (2003). Xylosandrus crassiusculus (Motschulsky) a bark beetle new to Europe (Coleoptera Scolytidae). Redia, Vol. 86, pp. 77-80, ISSN 0370-4327

Pennacchio, F.; Faggi, M.; Gatti, E.; Caronni, F.; Colombo, M. \& Roversi, P.F. (2004). First record of Phloeotribus liminaris (Harris) from Europe (Coleoptera Scolytidae). Redia, Vol. 87, pp. 85-89, ISSN 0370-4327

Péré C.; Augustin S.; Turlings T. C. J. \& Kenis, M. (2010). The invasive alien leaf miner Cameraria ohridella and the native tree Acer pseudoplatanus: a fatal attraction? Agricultural and Forest Entomology, Vol. 12, No. 2, (May 2010), pp. 151-159, ISSN 1461-9563

Perrings, C.; Mooney, H. \& Williamson, M. (eds.) (2010). Bioinvasion and globalization. Ecology economics, management, Oxphord univ. press, ISBN 978-0-19-956015-8, New York

Pervez A. \& Omkar A. (2006). Ecology and biological control application of multicoloured Asian ladybird, Harmonia axyridis: A review. Biocontrol Science and Technology, Vol. 16, No. 2, pp.111-128, ISSN 0958-3157

Quacchia, A.; Ferracini, C.; Moriya, S., \& Alma, A. (2009). Italian experience in biological control of Dryocosmus kuriphilus. Proceedings of the Japan-Italy joint international symposium A Global Serious Pest of Chestnut Trees, Dryocosmus kuriphilus: Yesterday, Today and Tomorrow, pp. 14-17, Tsukuba Japan, 24-25 November 2009

Raineri, V.; Ray, A.; Marini, M. \& Zaffagnini, V. (2001). Un nuovo rinvenimento di Cryptotermes brevis in Italia (Isoptera). Bollettino della Società Entomologica Italiana, Vol. 133, No. 2, pp. 99-102, ISSN 0373-3491

Reinert, J. F.; Harbach R. E. \& Kitching I. J. (2004). Phylogeny and classication of Aedini (Diptera: Culicidae), based on morphological characters of all life stages. Zoological Journal of the Linnean Society, Vol. 142, pp. 289-368, ISSN 0024-4082 
Rigamonti, I.E. (2004). Contribution to the knowledge of Ceratitis capitata Wied (Diptera, Tephritidae) in Nortern Italy II. Overwintering in Lombardy. Bollettino di Zoologia agrarian e di Bachicoltura, Ser II, Vol. 36, No. 1, (April 2004), pp. 89-100, ISSN 03733491

Roques, A.; Rabitsch, W.; Rasplus, J. Y.; Vaamonde, C. L.; Nentwig, W. \& Kenis, M. (2009). Alien terrestrial invertebrates of Europe. In: Handbook of Alien Species in Europe, Drake J. A., pp. (63-79), Springer, ISBN 978-1-4020-8279-5

Roversi, P. F.; Strong, W. B.; Caleca, V.; Maltese, M.; Sabbatini Peverieri, G.; Marianelli, L.; Marziali, L. \&. Strangi, A. (2011). Introduction into Italy of Gryon pennsylvanicum (Ashmead), an egg parasitoid of the alien invasive bug Leptoglossus occidentalis Heidemann. EPPO Bulletin, Vol. 41, No. 1, (April 2011), pp.72-75, ISSN: 1365-2338

Sacchetti, P.; Camera, A.; Granchietti, A.; Rosi, M.C. \& Marzialetti, P., (2005). Prima segnalazione in Italia del curculionide delle palme, Rhynchophorus ferrugineus, 15.02.2011, Available from: http://www.cespevi.it/art/rhynco.htm

Sakai, A.K.; Allendorf, F.W.; Holt, J.S.; Lodge, D.M.; Molofsky, J.; With, K.A.; Baughman, S.; Cabin, R.J.; Cohen, J.E.; Ellstrand, N.C.; McCauley, D.E.; O’Neil, P.; Parker, I.M.; Thompson, J.N. \& Weller, S.G., (2001). The population biology of invasive species. Annual Review of Ecology, Evolution, and Systematics, Vol. 32, (November 2001), pp. 305-332, ISSN 1543-592X

Sama, G. \& Bocchini, R. (2003). Phoracanta recurva Newman, 1840 (Insecta Coleoptera Cerambycidae) prima segnalazione per la fauna italiana. Quaderno della Società per gli Studi Naturalistici della Romagna, Vol. 18, (December 2003), pp. 168, ISSN 11236787

Savoldelli, S. \& Lupi, D. (2008). New breeding grounds of Reticulitermes lucifugus (Rossi) (Isoptera Rhinotermitidae) in Lombady (Italy). Bollettino di Zoologia Agraria e di Bachicoltura, Ser II, Vol. 40, No. 1, (April 2008), pp. 91-94, ISSN 0336-2403

Scarpelli, F. \& Bosio, G. (1999). Echinothrips americanus Morgan, nuovo tisanottero delle serre. L'Informatore Agrario, Vol. 55, No. 2, (January 1999), pp. 59-61, ISSN 0020-0689

Servadei, A. (1966). Un tingide neartico comparso in Italia (Corythucha ciliata Say). Bollettino della Società Entomologica Italiana, Vol. 96, pp. 94-96, ISSN 0020-0689

Shang, H.; Stout, M.J.; Zhang, Z. \& Cheng, J. (2004). Rice water weevil (Coleoptera: Curculionidae) population dynamics in Luoisiana. Journal of Entomological Science, Vol. 39, No. 4, pp. 623-642, ISSN 0749-8004

Strapazzon, A. \& Girolami, V. (1983). Infestazioni fogliari di fillossera (Viteus vitifoliae (Fitch)) con completamento dell'olociclo su Vitis vinifera (L.) innestata. Redia, Vol. 66, pp. 179-194, ISSN 0370-4327

Strauss, G. (2009). Host range testing of the nearctic beneficial parasitoid Neodryinus typhlocybae. Biocontrol, Vol. 54, No. 2, (April 2009), pp.163-171, ISSN 1386-6141

Suarez, A.V.; Holway, D.A. \& Tsutsui, N.D. (2008). Genetics and behavior of a colonizing species: The invasive argentine ant. American Naturalist, Vol. 172, No. 1, (July 2008), pp. 72-84, ISSN 0003-0147

Süss, L. (1973). Reperti afidologici su alcune piante in serra nel Milanese. Bollettino di Zoologia agraria e Bachicoltura, Ser. II, Vol. 11, No.3, pp. 177-193, ISSN 0336-2403

Süss, L., (1992). Prima segnalazione in Italia di Liriomyza huidobrensis (Blanchard) (Diptera: Agromyzidae). Bollettino di Zoologia agraria e Bachicoltura Ser. II, Vol. 23, No. 2, (August 1992), pp. 197-202, ISSN 0336-2403

Süss, L.; Lupi, D. \& Savoldelli, S. (2008). Parassiti animali, In: Il riso, AA.VV. (2008), pp. 332353, Bayer CropScience, Ed. Script, Bologna 
Sutherst, R.W. (2000). Climate change and invasive species: a conceptual framework, In: Invasive Species in a Changing World, Mooney, H.A. \& Hobbs, R.J., eds, pp. 211-240, Island Press, ISBN 1-55963-781-1, Washington DC

Tan, K.; Li, H.; Yang, M.X.; Hepburn, H.R. \& Radloff, S.E. (2010). Wasp hawking induces endothermic heat production in guard bees. Journal of Insect Science, Vol. 10, (September 2010), pp. 1-6, ISSN 1536-2442

Tassi, F. (1970). Un longicorne australiano per la prima volta in Italia (Col. Cerambicidae). Bollettino dell'Associazione Romana di Entomologia, Vol. 24, pp. 69-71, ISSN 0004-6000

Tescari, G. (2001). Leptoglossus occidentalis, Coreide neartico rinvenuto in Italia (Heteroptera Coreidae). Lavori della Società Veneziana di Scienze Naturali, Vol. 26, pp. 3-5, ISSN 0392-9450

Tindall, K.V. \& Stout, M.J. (2003). Use of common weeds of rice as hosts for the rice water weevil (Coleoptera: Curculionidae). Environmental Entomology, Vol. 32, No. 5, (October, 2003), pp. 1227-1233, ISSN 0046-225X

Trematerra, P.; Zilli, A.; Valentini, V. \& Mazzei, P. (1997). Cacyreus marshalli, un lepidottero sudafricano dannoso ai gerani in Italia. Informatore Fitopatologico, Vol. 47, No. 7-8, (July-August. 1997), pp. 2-6, ISSN 0020-0735

Tremblay, E. \& Priore, R. (1997). Termite centro-americana in via di acclimatazione in Italia. L'Informatore Agrario, Vol. 53, No. 47, (December 1997), pp. 76-77, ISSN 0020-0689

Tremblay, E. ; Espinosa, B.; Mancini, D. \& Caprio, G. (2000). Un coleottero proveniente dal Sudamerica minaccia i pioppi. L'Informatore Agrario, Vol. 53, No. 48, (December 2000), pp. 89-90, ISSN 0020-0689

Valade, R.; Kenis, M.; Hernandez-Lopez, A.; Augustin, S.; Mari Mena, N.; Magnoux, E.; Rougerie, R.; Lakatos, F.; Roques, A. \& Lopez-Vaamonde, C. (2009). Mitochondrial and microsatellite DNA markers reveal a Balkan origin for the highly invasive horse-chestnut leaf miner Cameraria ohridella (Lepidoptera, Gracillariidae). Molecular Ecology, Vol. 18, No. 16, (August 2009), pp. 3458-3470, ISSN 0962-1083

Van Lenteren, J.C.; Babandrier, D.; Bigler, F.; Burgio, G.; Hokkanen, H.M.T.; Kuske, S.; Loomans, A.J.M.; Menzler-Hokkanen, I.; et al. (2003). Environmental risk assessment of exotic natural enemies used in inundative biological control. Biocontrol, Vol. 48, No 1, (February 2003), pp. 3-38, ISSN 1386-6141

Vicidomini, S. \& Dindo, M.L. (2006). Prima segnalazione europea di parassitizzazione di Cacyreus marshalli (Butler) da parte di un tachinide indigeno. Annali del museo civico di Rovereto, Vol. 22, pp. 213-218, ISSN 1720-9161

Viggiani, G.; Filella, F.; Delrio, G.; Ramassini, W. \& Foxi, C. (2009). Tuta absoluta, nuovo lepidottero segnalato anche in Italia. L'Informatore Agrario, Vol. 65, No. 2, (January 2009), pp. 66, ISSN 0020-0689

Wilson, S.W. \& McPherson, J.E. (1980). A list of the host plants of the Illinois Acanaloniidae and Flatidae (Homoptera: Fulgoroidea). Transactions of the Illinois State Academy of Science, Vol. 73, No. 4, pp. 21-29, ISSN 0019-2252

Yarbrough, J.A.; Armstrong, J.L.; Blumberg, M.Z.; Phillips, A.E.; McGahee, E. \& Dolen, W.K. (1999). Allergic rhinoconjunctivitis caused by Harmonia axyridis (Asian lady beetle, Japanese lady beetle, or lady bug). Journal of Allergy and Clinical Immunology, Vol. 104, No. 3, (September 1999), pp. 704-705, ISSN 0091-6749

Zangheri, S. \& Donadini, P. (1980). Comparsa nel Veneto di un omottero neartico: Metcalfa pruinosa Say (Homoptera, Flatidae). Redia, Vol. 63, pp. 301- 305, ISSN 0370-4327 


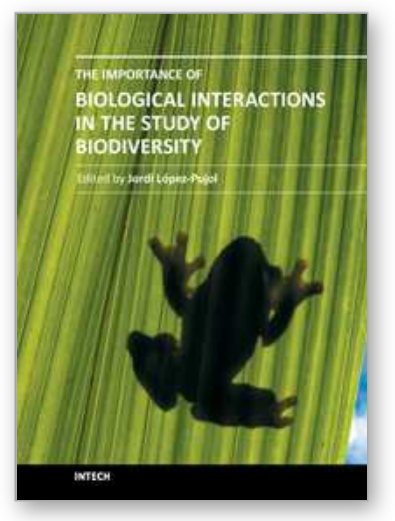

\section{The Importance of Biological Interactions in the Study of Biodiversity}

Edited by Dr. Jordi LÃpez-Pujol

ISBN 978-953-307-751-2

Hard cover, 390 pages

Publisher InTech

Published online 22, September, 2011

Published in print edition September, 2011

The term biodiversity defines not only all the variety of life in the Earth but also their complex interactions. Under the current scenario of biodiversity loss, and in order to preserve it, it is essential to achieve a deep understanding on all the aspects related to the biological interactions, including their functioning and significance. This volume contains several contributions (nineteen in total) that illustrate the state of the art of the academic research in the field of biological interactions in its widest sense; that is, not only the interactions between living organisms are considered, but also those between living organisms and abiotic elements of the environment as well as those between living organisms and the humans.

\section{How to reference}

In order to correctly reference this scholarly work, feel free to copy and paste the following:

Costanza Jucker and Daniela Lupi (2011). Exotic Insects in Italy: An Overview on Their Environmental Impact, The Importance of Biological Interactions in the Study of Biodiversity, Dr. Jordi LÃpez-Pujol (Ed.), ISBN: 978953-307-751-2, InTech, Available from: http://www.intechopen.com/books/the-importance-of-biologicalinteractions-in-the-study-of-biodiversity/exotic-insects-in-italy-an-overview-on-their-environmental-impact

\section{INTECH}

open science | open minds

\section{InTech Europe}

University Campus STeP Ri

Slavka Krautzeka 83/A

51000 Rijeka, Croatia

Phone: +385 (51) 770447

Fax: +385 (51) 686166

www.intechopen.com

\section{InTech China}

Unit 405, Office Block, Hotel Equatorial Shanghai

No.65, Yan An Road (West), Shanghai, 200040, China

中国上海市延安西路65号上海国际贵都大饭店办公楼 405 单元

Phone: +86-21-62489820

Fax: $+86-21-62489821$ 
(C) 2011 The Author(s). Licensee IntechOpen. This chapter is distributed under the terms of the Creative Commons Attribution-NonCommercialShareAlike-3.0 License, which permits use, distribution and reproduction for non-commercial purposes, provided the original is properly cited and derivative works building on this content are distributed under the same license. 